\title{
Global integration along historic pathways: Vienna and Munich in the changing financial geography of Europe
}

European Urban and Regional Studies 2014, Vol. 21 (4) 463-483

(C) The Author(s) 2012

Reprints and permission: sagepub.co.uk/journalsPermissions.nav DOI: | 0.1 | $77 / 09697764|2457| 72$ eur.sagepub.com

@SAGE

\author{
Hans-Martin Zademach \\ Catholic University Eichstätt-Ingolstadt, Germany
}

\section{Robert Musil}

Austrian Academy of Sciences, Austria

\begin{abstract}
Taking the two second-tier financial centres Munich and Vienna as illustrative cases, this paper empirically evaluates the extent to which the restructuring of the banking and insurance industry and the emergence of new financial agents calls for a reappraisal of the geography of European finance against longer-term developments. Conceptually, the paper adopts an evolutionary perspective that conceives inter- and intra-sectoral corporate takeovers and mergers and the rise of the private equity industry as driving forces for diversification/specification of financial centres. The paper traces the historic origins and long-term evolution of financial services in Munich and Vienna and then provides a twofold investigation of new empirical data: first a static investigation of the location networks of the 50 largest private equity firms and the 30 most important European banks; and second a network analysis of 493 merger and acquisition transactions in the European banking and insurance industries between 1997 and 2009 . The study reveals the varying roles that Munich and Vienna play today in Europe's financial geography and elucidates to what extent this variation results from both longer-term and more recent developments.
\end{abstract}

\section{Keywords}

Financial centres, Munich, network analysis, path dependency, Vienna

\section{Introduction}

Since Friedmann (1986) and Sassen (1991) introduced their influential work on world/global cities, there has been a rapid growth and diversification of the literature examining the importance of, and the interrelationship between, international financial centres (IFCs). Whereas during the 1990s this literature was dominated by descriptions of success stories of Anglo-American IFCs (Engelen and Grote, 2009: 692), a number of recent studies have paid increasing attention to second-tier financial centres in Europe. Both case studies of individual IFCs (e.g. Engelen, 2007; Grote, 2008; Wójcik, 2007) and comparative research addressing the system of European financial

\section{Corresponding author:}

Hans-Martin Zademach, Catholic University Eichstätt-Ingolstadt, Ostenstr. 18, D-85072 Eichstätt, Germany.

Email: zademach@ku.de 
centres at large (e.g. Faulconbridge et al., 2007) have contributed to our understanding of the shape of the landscape of financial centres in Europe and beyond. Probably the most encompassing comparative record of financial centres is the Global Financial Centres Index (GFCI) commissioned and published biannually since March 2007 by the City of London's Z/Yen group. ${ }^{1}$ According to this series of reports, less diversified second-tier financial centres show a lower degree of stability in their competitiveness and are less resilient towards economic cycles than the topranking centres, that is London and New York (e.g. Z/Yen, 2010: 1; see also Table 5 in Appendix). Munich and Vienna, which experienced a drop in the rankings between 2007 and 2010 from 29th to 33rd and from 35 th to 43 rd place respectively, provide good examples reflecting this trend. ${ }^{2}$

When it comes to explaining the uneven development patterns of financial centres, the relative shortness of the time period covered since the GFCI was first launched presents a considerable drawback. Not surprisingly, the proposed 'profile map' (Z/Yen, 2010: 5), which distinguishes different types of financial centres by taking into account how well these centres are connected in the global financial architecture and how diversified they are, lacks a dynamic perspective, that is it does not account for possible long-term transformations such as a strategic reorientation of financial service firms and the consequent functional up/downgrading of a financial centre. Similarly, Karreman's (2009) snapshot of the contemporary financial geography of central and eastern Europe is limited to the year 2007 and thus does not provide any elaboration of changes over time. Overcoming this shortcoming by means of an investigation of the two aforementioned second-tier financial centres, Munich and Vienna, against the background of their economic histories is a key purpose of this paper.

Along with providing two additional case descriptions to the existing collection of financial centre studies, this paper has two aims. The first one is to provide a conceptualisation of financial centres through an evolutionary network perspective that accounts for the global interconnections and the diversity and/or speciality of IFCs evolving over time. For this purpose, the following section merges arguments from three different strands of reasoning in the literature on financial centres and conceptualises the emergence of new financial agents, that is the private equity industry in the case of the present study, and corporate takeovers and mergers as driving forces for diversification/specification and restructuring. The second aim has a methodological task, namely to demonstrate the value of an application of social network analysis for empirical work on financial centres. In this concern, new empirical results are presented that draw first on a static exploration of the location networks of the 50 largest private equity firms and the 30 most important European banks, and second on a dynamic investigation of an overall total of 493 mergers and acquisitions (M\&As) transaction in the European banking and insurance industries between 1997 and 2009. Together, these results reveal the varying roles Munich and Vienna play today in Europe's financial geography: Vienna, the sole financial centre in Austria, which is heavily dominated by national banks, could gain an outstanding position in the provision of finance in the emerging eastern European market. Munich, in contrast, although playing only a subordinate role in banking in the national market, displays increasing international centrality for the insurance industry and ranks today among Europe's top addresses for private equity firms.

The remainder of this paper is structured as follows: the next section reviews the literature and argues for an evolutionary network perspective when examining IFCs. Following on from this perspective, we contextualise the two case studies by tracing back the evolution and diversification of financial services in Vienna and Munich to their historical roots. The fourth section makes the point for the application of social network analysis in studying financial centres, alongside specifying the foundations of the twofold empirical investigation reported here. The findings of this investigation are then presented, thereby elucidating to what extent the varying roles of Munich and Vienna in today's geography of financial centres in Europe are a result of both longer-term and more recent developments. The final section provides concluding remarks. 


\section{Financial centres and path dependencies: literature review and theoretical considerations}

Our understanding of the production and shape of the landscape of financial centres in Europe and beyond have been significantly increased by a range of geographical studies over the last decade (Table 1). These studies have demonstrated the advantages of a network model in exploring financial centres at the expense of a simplistic competition model, or the comparison of simple attributive properties (Beaverstock et al., 2001; Faulconbridge, 2004). In this way, both detail-rich case studies addressing the rise and/or

Table I. Established drivers in the evolution of financial centres and networks.

\begin{tabular}{|c|c|c|}
\hline Author(s) & Financial centres addressed & Key findings \\
\hline $\begin{array}{l}\text { Beaverstock et al. } \\
(200 \mathrm{I})\end{array}$ & London and Frankfurt & $\begin{array}{l}\text { Confirmation of a network model of inter-city relations at the } \\
\text { expense of the simplistic competition model }\end{array}$ \\
\hline $\begin{array}{l}\text { Faulconbridge } \\
(2004)\end{array}$ & London and Frankfurt & $\begin{array}{l}\text { Identification of London's dominance and Frankfurt's growth as } \\
\text { a complementary centre and demonstration of the explanatory } \\
\text { power of an examination of the networks and interdependencies } \\
\text { of financial centres (instead of attribute properties) }\end{array}$ \\
\hline Engelen (2007) & Amsterdam & $\begin{array}{l}\text { Demonstration of the fruitfulness of a long-term historical } \\
\text { approach, combined with a clear sensibility for the institutional } \\
\text { underpinnings of these long-term developments }\end{array}$ \\
\hline $\begin{array}{l}\text { Faulconbridge } \\
\text { et al. (2007) }\end{array}$ & $\begin{array}{l}\text { European IFCs and } \\
\text { Amsterdam }\end{array}$ & $\begin{array}{l}\text { Product complementarities, the nature of local epistemic } \\
\text { communities, and regulation are important; intertwined factors } \\
\text { affecting the competitiveness of financial centres with contingent } \\
\text { effects on change }\end{array}$ \\
\hline Wójcik (2007) & Warsaw & $\begin{array}{l}\text { Reconfigurations of the geography of stock exchanges are } \\
\text { primarily driven by the development of international networks of } \\
\text { stock market institutions; stock exchanges and financial centres } \\
\text { remain crucially important for each other }\end{array}$ \\
\hline Grote (2008) & Frankfurt & $\begin{array}{l}\text { Frankfurt emerged as the pre-eminent financial centre of Germany as } \\
\text { a result of the 'historical event' of setting up the German central bank } \\
\text { in Frankfurt; after a strong increase, Frankfurt's share in the location } \\
\text { of foreign banks in Germany decreased since the mid-1980s }\end{array}$ \\
\hline $\begin{array}{l}\text { Engelen and } \\
\text { Grote (2009) }\end{array}$ & Amsterdam and Frankfurt & $\begin{array}{l}\text { Virtualisation of stock exchanges/replacement of physical trading } \\
\text { leads to further centralisation of the financial sector in a limited } \\
\text { number of truly global financial centres and contributes to the } \\
\text { decline of second-tier financial centres }\end{array}$ \\
\hline $\begin{array}{l}\text { Hall and } \\
\text { Appleyard (2009) }\end{array}$ & London & $\begin{array}{l}\text { Business education, i.e. the (re)production of highly skilled financiers } \\
\text { and the assembling of financial expertise, represents an important } \\
\text { set of activities in understanding the continued geographical and } \\
\text { organisational heterogeneity of elite financial labour markets }\end{array}$ \\
\hline Karreman (2009) & $\begin{array}{l}\text { Europe with special } \\
\text { reference to Athens, } \\
\text { Vienna, Copenhagen and } \\
\text { Stockholm }\end{array}$ & $\begin{array}{l}\text { Development of the financial centres in Europe is largely dependent } \\
\text { on foreign investments and the power to attract multinational } \\
\text { financial service firms as well as the strategic position in the } \\
\text { growing markets of central and eastern Europe }\end{array}$ \\
\hline Schamp (2009) & Frankfurt & $\begin{array}{l}\text { Application of cluster approach (developed for industrial sector) } \\
\text { difficult for financial economy. Multiscalar perspective on the value } \\
\text { networks in the production process of financial products indicates } \\
\text { that only certain parts are knowledge based; non-repetitive } \\
\text { transactions require local proximities }\end{array}$ \\
\hline
\end{tabular}


Table I. (Continued)

\begin{tabular}{lll}
\hline Author(s) & Financial centres addressed & Key findings \\
\hline $\begin{array}{l}\text { Bassens et al. } \\
\text { (201I) }\end{array}$ & $\begin{array}{l}\text { Gulf IFCs, London, New } \\
\text { York }\end{array}$ & $\begin{array}{l}\text { Application of a network concept on Islamic financial services } \\
\text { provides evidence for the globalisation of this industry and shows } \\
\text { how cities are connected through interlocking board memberships } \\
\text { of a global Shari'a elite that also link up Gulf IFCs with London and } \\
\text { New York }\end{array}$ \\
Wójcik (2011) & $\begin{array}{l}\text { New York-London axis, } \\
\text { selection of further IFCs }\end{array}$ & $\begin{array}{l}\text { A combination of commonalities and complementarities has driven } \\
\text { the connectivity of the two leading global financial centres New } \\
\text { York and London. The power of this axis is embedded within its } \\
\text { relations with other financial centres and should not be expected } \\
\text { to decline }\end{array}$ \\
\hline
\end{tabular}

Source: authors' compilation.

IFC: international financial centre.

decline of single financial places (e.g. Engelen, 2007; Grote, 2008; Kruse, 2005; Schamp, 2009; Wójcik, 2007) and work on the system of financial centres in Europe as a whole (e.g. Faulconbridge et al., 2007; Wójcik, 2011; see also Lai, 2012) have shown that financial centres profit from a conducive interplay of geographically proximate and distant relations. These relations may result from the international networks of financial service institutions (Karreman, 2009; Wójcik, 2007), the personal networks of financial service professionals established, for example during business education (Hall and Appleyard, 2009; see also Bassens et al., 2011), or local and trans-local forms of collaboration when working out complex financial solutions and products, such as stock certificates or syndicated loans (Schamp, 2009; Zademach, 2009, 2011).

A further advancement in the examination of financial centres is the application of a long-term historical or evolutionary approach. In a nutshell, the evolutionary approach argues that 'the explanation to why something exists intimately rests on how it became what it is' (Dosi, 1997: 1531; for an overview see, for example, Boschma and Martin, 2010; Frenken and Boschma, 2007; Schamp, 2003). As Engelen (2007) convincingly demonstrates in his work on Amsterdam, the evolutionary approach is particularly fruitful if combined with a clear sensibility for the institutional underpinnings of these long-term developments. In this manner, Grote (2008) is able to show that Frankfurt emerged as the pre-eminent financial centre of Germany as a result of the 'historical event' of setting up the German central bank in Frankfurt. Likewise, Wójcik (2011) plausibly associates the increasing power of the New York-London axis with a number of regulatory changes, such as the shift to floating currencies in the 1970s, the consistent financial deregulation in the USA and the UK during the 1980s and the accelerated financial integration in the European Union during the 1990s and 2000s.

A third line of reasoning - linked to the wellestablished debate in regional science on urbanisation versus localisation economies (Marshall-ArrowRomer vs. Jacobs externalities) - argues that financial centres can show either a certain degree of diversity (i.e. breadth of industry sectors) or specialisation (the quality and depth of a certain industry such as investment banking or insurance) (Z/Yen, 2010: 4). The global leaders of financial centres - including London, New York, Hong Kong and Singapore - are considered to fulfil both; thus, they display a range of financial services or richness of the business environment that is both sufficiently broad and deep at the same time (see also Karreman and Van Der Knaap, 2009).

Taking these lines of reasoning together - the network model, the historical-institutional approach and the diversification-specialisation argument we suggest conceptualising IFCs as nodes of the financial service industry with their global interconnections as well as their diversity and/or speciality evolving over time (see also Clark and Wójcik, 
2005; Schamp, 2009). In other words, we regard financial centres as places that combine external and internal sources of knowledge in specific, changing combinations of regional characteristics i.e. growth in number of financial service firms in general (diversification) or in a particular industry (specification) - that can be understood as an evolutionary path. These paths are determined by former positions, yet both the actors located in a centre and third parties (e.g. government, non-residential firms) have the ability to influence these paths through mechanisms that provide selection and generate variation (Martin, 2006: 69n.; see also Martin and Sunley, 2006).

With respect to variation and the diversity of financial services, the last two decades brought forward a myriad of new financial innovations (Clark and Wójcik, 2007; Engelen, 2003; Klagge, 2004). In particular, there has been a spectacular growth of the private equity industry. Between 1985 and 2005, private equity funds experienced an annual growth of $18.5 \%$. In 2007, a record of more than US\$680 billion of private equity was invested globally, up over a third from the previous year and more than twice the total invested in 2005 (Private Equity Online, 2007). ${ }^{3}$ The boom of private equity provoked increasing concerns among economic and political actors, and the business model of private equity firms is often viewed extremely critically. Most notably, private equity firms are accused of destroying long-term values in their portfolio firms with accordant local and regional development consequences such as the disembedding of the regional social relations of ownership and control caused by the concentration of shareholding among institutional investors. On the other hand, recent studies (Folkmann et al., 2007; Klagge and Peter, 2009; Zademach, 2009) make the point that the agendas of financial investors, including private equity firms, may also have the effect of encouraging an economy of permanent restructuring and can serve as powerful means of preventing or breaking out of declining to 'locked-in' modes of production through the exchange of knowledge with various external partners.

In regards to selection mechanisms, evolutionary economics acknowledges first of all the role of the market in influencing how a technological paradigm emerges and develops. Market penetration and adjunct location decisions - as already indicated in the example of Frankfurt above - are accordingly another mechanism that may lead to major restructuring and changes in the courses of development of an IFC. Location decisions of banks and the resultant subsidiary networks generally tend to be rather stable, with, however, one significant exception: corporate M\&As. Both mergers/acquisitions of banks with/of other banks as well as of banks with/of other financial service providers (e.g. insurance companies) represent a drastic relocation of headquarters and of economic decision-making (Zademach and Rodríguez-Pose, 2009: 767; see also Musil, 2009). Although the impact of M\&As does not always imply a relocation of the physical means, the shift in decision-making power from the acquired to the bidding firm has profound implications for the evolution of regional economies. In particular, cross-border M\&As facilitate the international movement of capital, technology and services, and the integration of affiliates into global networks, and may be very effective in terms of capital accumulation, employment effects, technology transfer, increased competition and efficiency gains.

Both the emergence of new financial agents as a consequence of financial innovations and the expansion of corporate networks through takeovers and subsidiaries will be explored further as agents of change and indicators for diversification in the empirical part of this paper. The results of the network analysis will then exemplify the extent to which the rise of private equity firms and M\&As in the financial services industry over the last decade have affected the two IFCs Munich and Vienna and how this has had an impact on the financial geography of Europe as a whole. The next section will first sketch out the varying development paths of these two second-tier financial centres in order to account for the claimed significance of longer-term developments and path dependency.

\section{Research context}

According to the March 2010 edition of the GFCI, Munich and Vienna are both placed in the bottom third 
among the top 15 European financial centres, and both are classified as 'transnational diversified centres', that is they are connected at mid-level to other financial centres and display a relatively broad range of services. However, they show different historic origins and development paths, as they have been affected by differing historic accidents and are embedded into different national market and institutional environments with significant influence on the competitiveness and innovatory power on the financial service industries in both places, and thus on the evolution on Munich and Vienna as international financial centres.

\section{The case of late blooming Munich: Isar capitalism and weakening of the finance-industry nexus}

From the Middle Ages until the first half of the eighteenth century, Munich played only a subordinate economic role in Bavaria, with the imperial cities Augsburg, Nuremberg and Regensburg being the stronger (financial) centres. The meagre financial services that existed in Munich at this time served merely to cover the needs of the court. Thus, until the middle of the nineteenth century, internal selffinancing dominated (Wagner-Braun, 2007: 48). Craftsmen and the existing small businesses expanded predominantly on the basis of their running income; if external financing was involved, it was usually provided by means of loans from relatives or friends (Graff, 2000: 146). The finance sector was therefore hardly involved in the financing of industrial enterprises (cf. Borchardt, 1985: 162n; Fohlen, 1985: 106n). Only with the foundation of the private banks, whose rise is closely connected with the history of the Bankhaus Merck Finck in 1870, were external financing possibilities improved (compare also Table 6 in Appendix).

From the second half of the nineteenth century onwards, banks played an essential role in supporting industrialisation (Supple, 1976: 218n). Also, the significance of the mortgage business with house owners and commercial enterprises rose continuously (Jungmann-Stadler, 1988: 151). In particular, the expansion of house building correlates positively with the increasing relevance of mortgages (Gömmel, 2007: 102n). The growth of banking thus displayed a strong local nexus. Single banks such as the Vereinsbank focused their business activity on financing the growing Munich industry, allowing their loan business to grow rapidly. Others specialised in the private customer business. Generally speaking, industrial banks and investment banks took over the financing of industry and housing, while the national savings bank Sparkasse and the cooperative Volks- und Raiffeisenbanken were responsible for the broader public (Wagner-Braun, 2007: 87). This functional separation was reflected in a pronounced spatial arrangement: because of the reluctance of the investment banks to establish a network of branches, the financial place was identified by the spatial concentration of the juridical locations of the institutes (Kürten, 2006: 78).

In the post-war period, Munich gained significance as a location for high-growth technology sectors such as microelectronics, the aerospace industry and biotechnology. In the view of the state government, a distinct orientation towards science was regarded as a key element in the economic modernisation of Bavaria (Deutinger, 2001: 7). Politicians were aware of the significance of an adequate technical and financial infrastructure and thus promoted measures that increased the attractiveness of the region for financial institutions. This special relationship between economy and policy is also referred to as 'Isar capitalism' (LfA Förderbank Bayern, 2001: 69); the relocation of large German industrial enterprises and insurance companies to Munich were typical of this. In the early 1950s, not only Siemens but also Allianz moved to Munich. A major reason for this relocation was the long-established close relation between Allianz and the insurance company Münchner Rück. Similar reasons led to the relocation of banks to Frankfurt: the economic council of the American and British occupation zones was located in Frankfurt; thus, important decisionmakers came to the city and influenced the settlement of the banks. Both the formation of Frankfurt as the national centre for banking and the development of Munich as a strong insurance location are thus to be seen against the background of the political turmoil following the Second World War.

The 1960 s were characterised by a distinct parallel development of the local economy and credit 
business: the regional banks saw themselves as a partner of the local economy and adapted themselves to the increasingly complex needs of their customers. This coherence was blurred during the 1970s: with the end of the Bretton Woods system of fixed exchange rates, it became increasingly necessary to hedge the risk of foreign exchanges by means of futures and forwards. In consequence, further derivative financial products were developed; assetbacked forms of financing became established as an alternative to classic credit finance. At the same time, the oil crisis led to a decline in the domestic loan business. To be able to continue to promote growth and to reduce their dependence on the regional economy, banks were forced to expand abroad. In order to participate in local capital markets, they established overseas branches in the new markets in the form of subsidiaries. Additional liquidity could be created by the securitisation of assets leading to an increase in the supply of capital to the banks (Zeitler, 2007: 218n). However, the increasing opportunities for speculation arising from the increase in derivative instruments in the world of finance bore only little relation to the development of the real economy.

During the 1990s, regional economic policy repeatedly contributed to strengthening Bavaria as a location for business in general and Munich as a financial centre in particular in national and international competition. With the assistance of the regional government, the Bayerische Hypothekenund Wechselbank and Bayerische Vereinsbank merged in 1998 to become the Bayerische HypoVereinsbank HVB. In terms of the total assets on its balance sheet as well as its market capitalisation, this institute represented the second largest bank in Germany at the time. Its mortgage servicing subsidiary HVB Real Estate AG (Hypo Real Estate from 2003 onwards) - an institution that emerged in 2001 from a merger of the real estate and financing banks Nürnberger Hypothekenbank, Süddeutsche Bodencreditbank and Bayerische Handelsbank - became a leading bank in real estate and public financing with a European reach, which, however, encountered massive financial difficulties during the global financial crisis (see also 'Empirical results' section below).
In sum, the evolution of Munich displays a clear mutual connection between the economic growth in the region and the development of the location as a financial centre up to the beginning of the 1970s. A dynamic regional economy generated demand for financial services, and an efficient financial industry correspondingly assumed an important catalyst function for investments and growth. From the middle of the 1970s, this relation of mutual dependence between banks and enterprises at the local level became temporarily blurred under the influence of the introduction of new financial products and the increasing significance of the capital markets. During the 1990s and the last decade, this coherence has been strengthened again and, in consequence, Munich has become an attractive headquarters and investment location for a variety of agents in the international arena of finance.

\section{The case of Vienna: state dominance and easternisation in changing geopolitics}

Similar to the case of Munich, the early development of Vienna as a financial centre was first driven by the strong influence of the state, which was the most significant shareholder of the local banking sector. Given this domination of the state, the geopolitical changes of late nineteenth and early twentieth centuries are distinctly reflected in the history and development path of Vienna as a financial centre.

In 1771, Empress Maria Theresia initiated the foundation of Vienna's stock market as the first in central Europe, albeit some 300 years after Antwerp and 200 years later than London (Resch, 2006; Schmit, 2003; Wiener Börse, 2006; see also Table 7 in Appendix). Vienna was, however, never an eminent centre for mercantile and trade fairs; the stimulation to create a financial system came from the monarchy, which had a strong need to ensure its liquidity with the help of credit institutions. A near crash in 1845 as well as political incidents (the Revolution of 1848, military conflict in 1859 and 1866) led to a recession in the financial market. These politically and economically difficult times witnessed the establishment of large banks under state assistance (most notably public shareholding), among them the k.k. priv. Österreichische Credit 
Anstalt für Handel und Gewerbe, Bodencredit Anstalt, Anglo Österr. Bank, and Pfandleihgesellschaft (Schmit, 2003). This structural change, from a large number of smaller private banks towards a small number of large banks under state assistance, still affects the financial market of Vienna up to the present.

The economic boom phase of the first Gründerzeit (1866 to 1873 ) marked the period in which Vienna gained importance as a financial centre in the international arena. Industrialisation and the expansion of the railways led to a massive increase in investments and the establishment of many joint stock companies and speculative finance firms in Vienna. With the stock market crash of 1873 , this period came to an abrupt end and caused the downfall of the large majority of the investment banks, which had only recently been founded. However, thanks to a decrease in speculation, the large banks managed to overcome this international crisis (Resch, 2006). Since then, they have dominated not only the market in loans for private households, but also the stock market and industry financing (Baltzarek, 2005). This advantageous position could be fostered in the following years, that is during the second Gründerzeit (1893 to 1914), when Vienna experienced a boom phase as a financial centre; as the dominant centre of a state of 56 million people, Vienna was the epicentre for the national financing of industry and railways as well as for international transactions. This period was characterised by an ongoing linkage between the banking sector and industry and railway companies, in the form of shareholding as well as personal ties. Furthermore, the financial system of the Austro-Hungarian monarchy showed increasing tendencies towards concentration. Just twelve Viennese banks dominated the national financial centre as well as regional financial markets (e.g. Prague and Budapest) controlled by a dense network of subsidiaries (Baltzarek, 2005; Eigner, 2005; Eigner et al., 1991).

This development path ended abruptly with the First World War when Viennese financial services lost all international relevance for two reasons. First, capital assets of nobility and bourgeoisie melted away during the war; second, major assets were expropriated in the states emerging from the former monarchy (e.g. Hungary, Romania and Czechoslovakia). This caused a lack of investment capital on the financial market in Vienna (Schmit, 2003; Stiefel, 2006). Furthermore, the stagnating Austrian economy provided only very few opportunities for attractive investments, because most industrial zones and railway projects were located in the new states. In consequence, Viennese banks tried to enter their eastern neighbour states again, yet faced severe opposition in these countries because of a defensive attitude towards the former powerhouse of the monarchy. The collapse of Creditanstalt in 1931, Austria's most important bank at that time, marked the end of efforts to establish Vienna as a significant centre for finance in central and eastern Europe (Butschek, 2009). Seen as a whole, the period of the Gründerzeit thus shows how strongly the rise and fall of Vienna as a financial centre was connected to geopolitical changes in the territory of the former monarchy, an observation that holds true up to the present (see 'Empirical results' section below).

The nexus between the state and the large banks, which survived the Great Depression and the two World Wars, was further strengthened in the period following the Second World War. In the context of the policy for reconstruction in the years after 1945, the oligopolistic banking sector was subject to rigid credit control by the government, allowing the state to dictate the modes of lending for specific sectors (Resch, 2006). For this reason, the Viennese banks became an essential instrument of the so-called Austro-Fordist economic policy. The Viennese stock exchange, on the other hand, was used more or less exclusively as a platform to place bonds of the Austrian state. However, this relatively stable development experienced a significant transformation through Austria's engagement in the European integration process in the 1980s and foremost after the fall of the Iron Curtain in 1989. Privatisation, liberalisation and the transformation process in eastern Europe fostered the internationalisation of Viennese banks. As they had managed to establish rather welldeveloped relations in this region during the Cold War, for example by means of processing the trade of industrial products between Austria and the Comecon countries (Komlosy, 2006), Austrian banks had significant competitive advantages in the new markets. These advantages resulted in the formation of a new development path with Vienna as an IFC from the 
1990s onwards, as will become particularly evident in the remaining, empirical part of this paper.

\section{Investigating the integration of Vienna and Munich into the European financial system: specification of analysis and network parameters}

Against the background of the historic origins and longer-term developments of financial services in Munich and Vienna, the remainder of this paper aims to comparatively address the factors driving these paths and the more recent developments through the use of social network analysis. This type of analysis, originally developed for ethnological and sociological studies during the 1970s and 1980s, has become a widely used method for social sciences in general (e.g. Freeman, 2005; Trappmann et al., 2005) as well as urban and regional studies and investigations of the world city network in particular (e.g. Krätke, 2002; Taylor, 2001, 2004). The concept of network theory is based on the idea that the sum of social interrelations between actors allows insights into the structure and dynamics of a social system as well as the social position of single actors (Jansen, 2003).

The empirical analysis presented in this study addresses three different datasets in two analytical steps. The first step reviews the situation of Munich and Vienna as IFCs in the year 2009. The data used in this step covers first the branches of Europe's top 30 banks on the basis of the publicly available Bankscope Database, and second, based on our own collection of data, the branch offices of the world's top 50 private equity firms according to the so-called PEI 50 (i.e. the annual ranking of the largest private equity firms in the world released by the industry magazine Private Equity International). The Bankscope data encompasses a total of 301 intra-firm relations between 47 European cities; the private equity network data encompasses 170 intra-firm relations between 37 European and 12 North American cities. On basis of this data, the first step pictures the varying characteristics, and the degree of integration into the international landscape of IFCs, of the two locations addressed here in more detail.
Both datasets used in the first analytical investigation are unfortunately not available for a longer period of time; thus, they offer only a snapshot in time and do not allow for a dynamic investigation. This limitation may be overcome in a second analytical step though using a set of data provided by Bureau Van Dijk, a commercial provider of data on the financial service industry. This data covers information regarding 493 M\&A transactions undertaken by European banks and insurance companies between 1997 and 2009 (the consideration of the insurance sector instead of the private equity (PE) industry - since, again, for the PE sector, no longitudinal data were available - follows our approach to accounting for the increasing differentiation of financial products and services). As discussed before, M\&As are potential agents of change and powerful indicators reflecting the internationalisation strategy of multinational financial service firms and their integration into the international financial centre system.

The Bureau Van Dijk dataset has been investigated by means of addressing three subperiods reflecting three significant economic cycles. The first cycle spans the period from 1997 to 2001 and showcases the period of the new economy boom; it covers 119 M\&A transactions. The second period, extending from 2002 to 2006 and encompassing 251 transactions, represents the heyday of financialised market capitalism. The final time span (2007 to 2009, 123 transactions) covers the time of the advent of the most recent global financial crisis.

The application of social network analysis offers a broad range of empirical outputs. Two of these are particularly valuable for the present study: on the one hand, the possibility of describing the characteristics of a network and its dynamics as a whole, and on the other hand the possibility of gaining insights into individual centres in this network, in this case the IFCs of Munich and Vienna. Four indicators are used to describe the overall network. The first of them is size, which depicts the number of actors and the number of relations in a network. The second indicator, density, builds on the relation of the number of links to the number of actors in a given network; a high density indicates a large 
number of interactions, but it provides no information about the dispersion of links between the actors/cities, for example whether the relations are concentrated within a small number of cities. This 'unevenness' of a network can be detected through the third parameter, centralisation, defined here as the share of relations of the top five cities in the network. The fourth indicator, regionalisation, displays the share of relations that have the same origin and destination, such as an M\&A transaction in which both the acquiring and the target firm were located in Vienna.

With regard to the description of individual IFCs, four further parameters are to be finally introduced. The degree centrality is the ratio of each centres' actual relations to its potential ties into the network as a whole, thus it indicates the strength of the integration of an IFC - thanks to a large number of headquarter-subsidiary relations of banks or PE firms, or M\&A targets and/or acquiring firms - into the European financial system. The two parameters out-degree centrality and in-degree centrality consider the direction of relations. A high out-degree centrality indicates that the various headquarters located in the respective city hold a huge number of subsidiaries and/or are the origin of many M\&A transactions. Similarly, a high in-degree centrality hints at a high level of integration, too, but in this case rather as a target of M\&As or as a location for subsidiaries. Built on these two indicators, the final parameter, balance, marks the ratio of outgoing and incoming centrality, thus specifying whether an IFC tends to be a centre for headquarters and acquiring firms, or one for subsidiaries and M\&A targets. As will be shown now, these individual network parameters prove helpful in the investigation of the evolutionary paths of the two IFCs of Munich and Vienna in the European landscape of financial centres.

\section{Empirical results: Vienna and Munich in the changing financial geography of Europe}

The subsequent discussion of the results of the network analysis follows the analytical two-step approach. The snapshot of the headquarter-subsidiary networks of the world's top 50 private equity firms and Europe's top 30 banks presented first displays the contemporary position of Munich and Vienna in the landscape of IFCs in 2009 (i.e. the results of longer-term developments of the financial service in the two places). The section then turns to the dynamic investigation that highlights the changes in the IFC network over the last decade as a result of M\&As in banking as well as the insurance industry and thus delivers insights that further our understanding of the development paths of Munich and Vienna in the financial geography of Europe.

\section{The contemporary financial geography of Europe}

With a dense network of branch offices and subsidiaries, the activities of the world's leading private equity firms and Europe's largest banks today span the entirety of Europe. Figure 1 displays these networks as a snapshot of the year 2009 and offers an indication of the overall involvement of the European IFCs in the global circuits of the financial economy. A number of important findings emerge from the exercise to map out the two networks and compare their basic characteristics through network analysis. First, and not surprisingly given the stage of development and general significance of the business models of banks and PE firms, the two networks demonstrate considerable differences as regards their sheer size and density. Measured in terms of the ratio between the number of interlinkages and the number of cities involved, the European banking sector exhibits a density (6.40) almost double the level in the network of the branch offices of the most important players in the PE sector (3.47, see also Table 2).

Second, it becomes evident that the branch offices of the world's leading PE firms - with their headquarters being located principally in the USA - are highly concentrated in a small set of specific cities: 25 of the 50 headquarters are to be found in just two cities, namely New York (15) and London (10). Other European cities play only a minor role as locations of one of the world's top PE firms, with two headquarters located in Paris, and one each in 


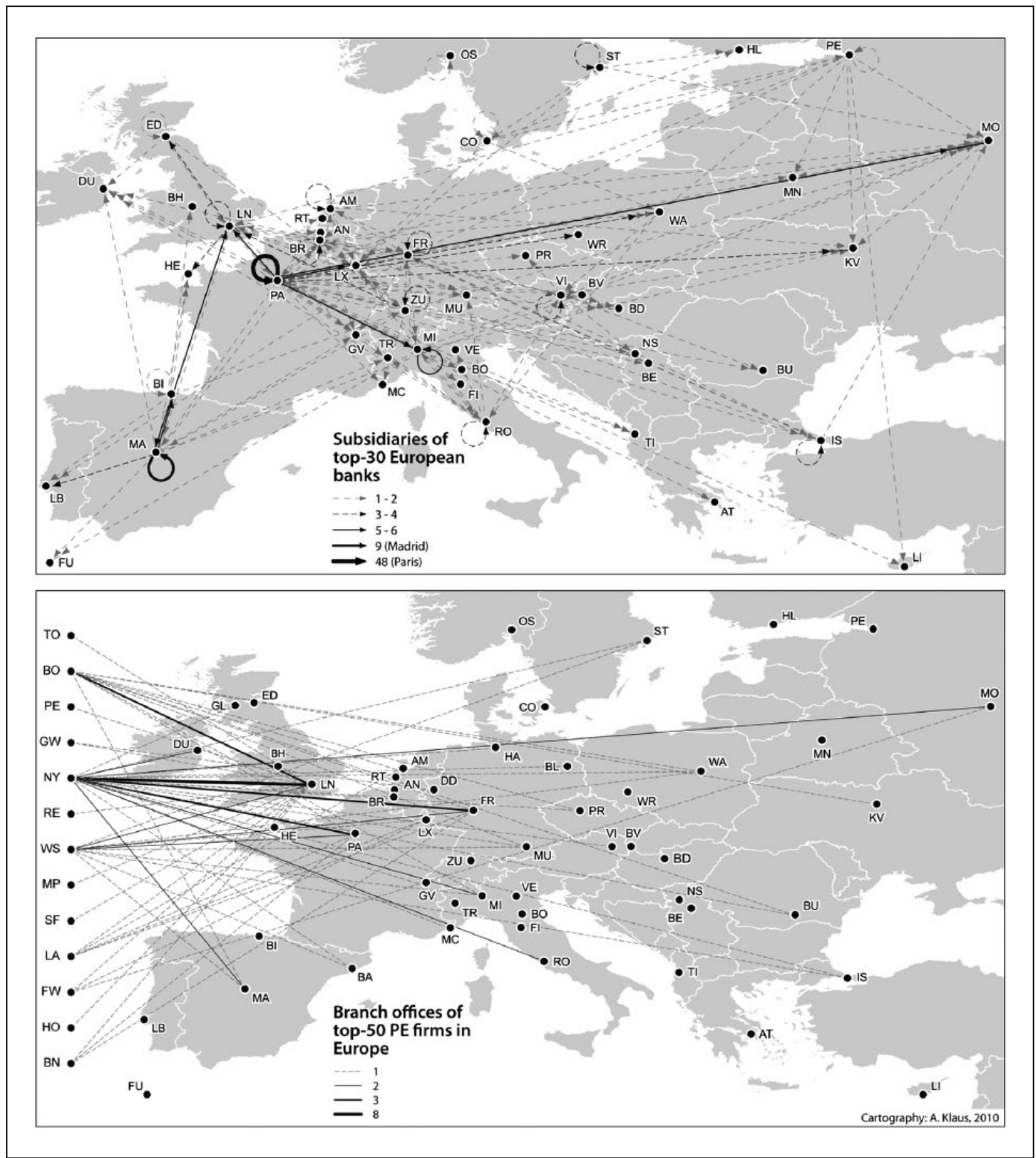

Figure I. Parent-subsidy relations of Europe's top 30 banks and the world's top 50 private equity firms across Europe, 2009.

Source: authors' illustration based on data from Bankscope Database and own data collection.

Luxembourg, Stockholm and Athens. In contrast, the network of the branches of Europe's top 30 banks shows, spatially, a much more diverse fabric. The large majority of these banks hold subsidiaries in a considerable number - up to 17 at the maximum
(Société Général) - of European cities. With four headquarters each, Paris and, again, London are the two IFCs where the highest number of leading European banks headquarters are located (Table 5 in Appendix). 
Table 2. Freeman's degree centrality measure of selected cities in the networks of Europe's top 30 banks and the world's top 50 private equity firms, 2009.

\begin{tabular}{lll}
\hline & Top 30 banks & Top 50 PE firms \\
\hline Vienna & 0.271 & 0.250 \\
Munich & 0.062 & 1.000 \\
London & 0.666 & 9.500 \\
Paris & 2.271 & 3.125 \\
Frankfurt & 0.312 & 2.000 \\
Luxemburg & 0.333 & 2.000 \\
Zurich & 0.333 & 0.750 \\
Genève & 0.125 & 0.250 \\
Descriptive statistics & & \\
Mean & 0.214 & 0.837 \\
SD & 0.345 & 1.551 \\
Density & 6.400 & 3.470 \\
Minimum & 0.021 & 0.125 \\
Maximum & 2.271 & 9.500 \\
\hline
\end{tabular}

Source: authors' calculations based on data from Bankscope Database and own data collection.

SD: standard deviation.

A further striking difference between the two networks relates to the presence of banks and PE firms and their respective degrees of interaction on the local level. While the considered PE firms run, in each case, only one branch office in a European city, a considerable share of the investigated banks hold multiple subsidiaries, that is functional head units, such as the investment banking division or the headquarters of an affiliated bank resulting from a merger or acquisition (local branch offices are not accounted for here), in one place. Accordingly, close to one third (100) of the total of 301 headquarter-subsidiary links are local (see Figure 1, again). Paris, accounting for nearly half of these links, as well as Madrid, Milan, Vienna, London and Frankfurt come into effect as outstanding places, thereby substantiating their position as recognised control nodes of the European banking industry.

With regard to the two IFCs of Munich and Vienna, a number of further indications emerge from this step of analysis. In the network of Europe's top 30 banks, Vienna shows a degree centrality $(0.271)$ that slightly exceeds the mean of the degree centrality of all cities covered in the network of the top 30
European banks, amounting to 0.214 (Table 2). One of Vienna's large banks Erste Bank is among these institutions; this bank holds seven subsidiaries in Europe, primarily in eastern Europe: Bratislava, Budapest, Prague, Kiev and Novi Sad. With regard to incoming links, three foreign top 30 banks hold a subsidiary in Vienna: Natixis (Paris), Unicredit (Rome) and VTB Bank (St Petersburg). In contrast, Vienna shows a low degree centrality in the network of PE firms (0.250, compared with a mean of 0.837$)$. Just one European link is related to Vienna (from the French AXA Private Equity); furthermore, AIG Investments, whose registered office is in Delaware, USA, and whose principal office is in New York, holds a subsidiary in Vienna. Together, these findings reflect that Vienna is predominantly a centre of the banking industry with a rather low degree of diversity, or in other words a rather deep (as opposed to broad) business environment for the financial service industry. In addition, the results of this step of the investigation point to the significance of the European integration process to this IFC and the marked engagement of the Viennese financial service industry in Central and Eastern European Countries.

Munich, in comparison, comes to the fore as a fairly diversified IFC, with, however, poor degree centrality (0.062; see Table 2$)$ in the banking sector. As already mentioned, Munich's largest bank HVB merged with the Viennese Bank Austria in 2000, but was itself acquired in 2005 by Italian Unicredit. In consequence, none of the top 30 bank headquarters are today located in Munich. Apart from HVB, two further banks hold subsidiaries in this IFC, namely Paribas Bank of Paris and KBC GROEP of Brussels. Yet Munich could gain significance as a location in the PE segment: 8 of the top 50 PE firms hold a branch office in Bavaria's capital (see also Table 5 in Appendix, again). Three of their parents are located in London (Apax Partners, Doughty Hanson \& Co, Barclays Private Equity), and one each in New York (Fortress Investment Group), Washington (The Carlyle Group) and Boston (Bain Capital) as well as Paris (PAI Partners) and Stockholm (EQT Partners). Thus, Munich alone accounts for close to $5 \%$ of the 170 branch offices held by the 50 leading PE firms worldwide, and almost one out of ten of all European branches is located here. Hence, PE firms are to be 
seen as a concurrent key driver for Munich's integration into the international financial system, with even stronger linkages to the core areas of global finance in comparison with Vienna. In addition, the city holds a prominent position in the insurance industry, as will be further elaborated below.

\section{Development paths in Munich and Vienna compared: results of the network analysis}

Turning finally to the dynamic investigation and thus the transformations in the network of IFCs in Europe over the last decade, Tables 3 and 4 report the results of the network analysis of the M\&A activities of European banks and insurance companies in the three subperiods specified above, first for the total network and then for Vienna and Munich individually. As far as the total network is concerned (Table 3 ), the parameters point to an overall fairly constant level of M\&A activities over the whole period of investigation in both banking and the insurance industry, with a marked peak in the second period, that is the heyday of financialised capitalism. On the banking side, the relatively stable parameters of centralisation (the share of the top five IFCs) and regionalisation (M\&A activities on the local level) indicate that these activities did not, however, affect the general landscape of Europe's financial geography, but rather perpetuated the dominance of the leading centres in European banking, above all London, Paris and Zurich. In the insurance sector, in contrast, the noticeable increase of the parameter centralisation from 0.43 in the late 1990 s to 0.69 during the global financial crisis (2007-2009) points to a growing dominance of the leading locations of this sector. As indicated by the likewise relatively high level of intra-regional transactions (regionalisation), this development is accompanied by pronounced endeavours for horizontal integration, and thus a distinct consolidation of the insurance market on the local and national level.

With regard to the development of Munich and Vienna in this multilayered environment of persistence and change, the individual network parameters in Table 4 reveal two different adjustment strategies. Vienna, on the one hand, comes into effect as an IFC with a continuously high degree centrality in the European banking landscape. During the first subperiod, this centrality results mainly from a particularly high in-degree centrality as a result of a number of acquisitions targeted at Viennese banks. The acquirers were primarily German banks, with the acquisition of Austria's largest bank, Bank Austria, through the Bavarian HVB being the most striking case. Subsequently, however, the

Table 3. Total network parameters, 1997-2009.

\begin{tabular}{lccc}
\hline Network parameter & $1997-2001$ & $2002-2006$ & 2007-2009 \\
\hline Banks & 52 & 85 & 65 \\
Size (no. of cities) & 82 & 202 & 104 \\
Size (no. of M\&As) & 1.58 & 2.38 & 1.60 \\
Density & 0.34 & 0.27 & 0.33 \\
Centralisation & 0.33 & 0.37 & 0.34 \\
Regionalisation & & & \\
Insurance & 30 & 44 & 20 \\
Size (no. of cities) & 37 & 49 & 19 \\
Size (no. of M\&As) & 1.23 & 1.11 & 0.95 \\
Density & 0.43 & 0.36 & 0.69 \\
Centralisation & 0.38 & 0.44 & 0.47 \\
Regionalisation & & &
\end{tabular}

Source: authors' calculations based on data from Bureau van Dijk. M\&As: mergers and acquisitions. 
remaining banks, particularly Raiffeisen International and Erste Bank, were able to reverse the negative balance - as indicated by a larger out-degree centrality in the second and third subperiod - with a large number of engagements in eastern Europe, targeting Prague, Bucharest, Belgrade, Bratislava and Moscow, among others. In this vein, Viennese banks were able to profit considerably from the economic growth in central and eastern Europe over the last decade, which allowed Viennese banks to expand further.

The role of the banks located in Munich, on the other hand, in the restructuring of the European financial sector has been less central. However, in contrast to Vienna, Munich shows a constantly positive balance of outgoing to ingoing M\&As, notwithstanding Unicredit's acquisition of HVB. The overall increase of the degree centrality (see Table 4, again) relates to a number of mergers on the national market as well as, again, in eastern Europe. Besides HVB, which had dominated the M\&As market at the national level prior to the acquisition by Unicredit, Bavarian Landesbank has been an important agent (acquiring, for example, Austrian HypoAlpeAdria in 2007 and Banque LBLux in 2009). As result of these acquisition activities, the network spanned by banks located in Munich today encompasses large parts of Germany (with subsidiaries in Bochum, Frankfurt and Stuttgart), western Europe (Luxembourg, Milan and Paris) and relatively distant locations in eastern Europe (Kiev and Moscow).
Parallel to these developments in the banking sector, Munich displays a rather prominent position in the insurance sector over the whole period of investigation. Again, the reported parameters reveal a distinct tendency towards consolidation: while Munich's insurance companies - with Munich RE and Allianz as the dominant players - were initially predominantly engaged in international acquisitions, mergers and takeovers on the local level (such as between Bayerische Beamtenkrankenkasse and BBV Krankenversicherung in 2008) regained importance at the end of the period of investigation. Vienna, on the other hand, experienced a substantial increase in significance as a headquarters location for insurance companies, inter alia as a result of the acquisitions of UNIQUA and Vienna Insurance Group in Warsaw, Bucharest and Tallinn as well as in Germany (Mannheimer Krankenversicherung).

In sum, the dynamic network analysis has unveiled a number of developments in the integration of the two second-tier IFCs Vienna and Munich into the global circuits of finance that are related to their historic preconditions in a particular marked manner. Most strikingly, both cities managed to a large degree to stabilise their respective positions in the European landscape of IFCs by means of regional and transnational M\&As. In this way, Munich could defend its supremacy in the insurance market, and the acquisitions of HVB and Bank Austria could be 'compensated' to a certain degree through M\&A activities on the national market

Table 4. Individual network parameters for Munich and Vienna, 1997-2009.

\begin{tabular}{|c|c|c|c|c|c|c|}
\hline Network parameter & \multicolumn{2}{|c|}{$|997-200|$} & \multicolumn{2}{|c|}{$2002-2006$} & $\begin{array}{l}\text { 2007-20 } \\
\text { Munich }\end{array}$ & Vienna \\
\hline \multicolumn{7}{|l|}{ Banks } \\
\hline Degree centrality & 0.250 & 1.250 & 0.545 & 1.091 & 0.500 & 1.000 \\
\hline In-degree & 0.481 & 1.923 & 0.107 & 0.214 & 0.256 & 0.769 \\
\hline Out-degree & 0.962 & 1.442 & 0.535 & 1.176 & 0.513 & 1.282 \\
\hline Balance (out-in) & pos. & neg. & pos. & pos. & pos. & pos. \\
\hline \multicolumn{7}{|l|}{ Insurance } \\
\hline Degree centrality & 0.667 & 0.333 & - & 0.250 & 0.5 & 1.5 \\
\hline In-degree & 0.556 & 0.556 & - & 0 & 2.5 & 2.5 \\
\hline Out-degree & 1.667 & 1.111 & - & 0.568 & 2.5 & 5 \\
\hline Balance (out-in) & pos. & pos. & - & - & $+/-$ & pos. \\
\hline
\end{tabular}

Source: authors' calculations based on data from Bureau van Dijk. 
and in neighbouring countries by the remaining banks. The breadth and depth of the banking industry that could emerge - under very different general conditions - in both places in the long run is to be seen an important prerequisite for this persistence.

In addition, both IFCs today show tendencies towards greater diversification. Vienna, as a financial centre that was initially characterised most notably by national banks, meanwhile displays increasing centrality and openness, not only through its strong focus on eastern Europe in banking, but also in the insurance sector. In Munich, diversification is driven by the strong foray into the PE market. So far, this is not the case in Vienna as a long-time strongly regulated and politically coordinated IFC. The mutual interdependence of the local economy and the local financial service industry that signified Munich's economic development for the longest time in its history, on the other hand, can reasonably be seen as a meaningful explanation for the reorientation towards a pronounced industryfinance nexus in this place. Thus, both the observed persistence and new path creations come into effect as being distinctly tied to past developments and the respective economic histories of the two IFCs.

\section{Conclusion}

The aim of the present study was to shed light on current changes in the landscape of European financial centres and to address the reconfiguration and global integration of the financial service industry against the background of long-term and recent macroeconomic cycles in Munich and Vienna as two illustrative cases. In so doing, the paper provides two additional financial centre studies to the existing collection of case descriptions. It also contributes by adding a temporal element to comparative investigations on financial centres by adopting longitudinal analysis, while existing work tends to represent snapshots of analysis based on data from a specific year. In addition, the study demonstrates the value of the application of network analysis for empirical work on financial centres.

The results of the analysis have revealed the different development courses of Vienna and Munich towards greater specialisation and diversification as well as the resulting roles to be attributed to these two IFCs in the contemporary European landscape of financial centres. Vienna, which was long state-dominated and strongly nationally orientated, at present holds an outstanding role when it comes to the provision of finance in the eastern European market. Munich, in contrast, only plays a subordinate role in banking today, even on the national market, but could gain international centrality for the insurance industry and private equity firms. Both trends display distinct relations to their particular historic roots and thus substantiate the explanatory capacity of the path dependency argument to explore financial geographies.

In line with this reasoning, the detected trajectories may be expected also to affect the future prospects of Munich and Vienna as IFCs. In view of the general persistence of the landscape of financial centres, these prospects seem, at first glance, rather limited. This holds principally true from a global perspective, that is if the dominance of AngloAmerican IFCs in new financial services and the rise of IFCs in Asia are taken into account. On the European scale, however, it appears fair to presume that further shifts and displacements will occur at the levels of second- and third-tier IFCs. In this regard, Munich can concurrently be perceived as occupying a more advantageous position owing to its greater diversification, while Vienna's distinct dependence on the Central and Eastern European Countries markets comes out as the riskier venture. Continuing to trace and shape these shifts is undoubtedly a challenging task in the currently insecure global economic environment. Both future research and public authorities would be well advised to take into account the longer-term evolutionary paths behind the uneven development of financial centres when addressing this issue in Europe and beyond.

\section{Funding}

Financial support of the Council of the City of Vienna is gratefully acknowledged.

\section{Acknowledgements}

The authors would like to express their gratitude to Andreas Koch for his helpful, always patient advice 
regarding the network analysis as well as to Kilian Gruen, Madeleine Koch, Jonas König and Antonia Osberger for excellent research assistance. They also thank Neil Coe, two anonymous reviewers, the participants of the session 'German Cities in the World City Network' at the AAG in Washington, and Philipp Rodrian for thoughtful comments on earlier drafts of this paper, and Katie Klaffenböck for great editing help. Naturally, the authors remain solely responsible for the content of the paper.

\section{Notes}

1. The GFCI uses a set of ratings and rankings based on (1) a range of external measures such as the Human Development Index and the Corruption Perception Index that aim to capture a financial centre's competitiveness, and (2) an online questionnaire completed by international financial service professionals.

2. It is noteworthy that since late 2010 , the time when the empirical research presented in this paper was conducted, Munich has experienced a steady increase in the GFCI ranking (up to rank 22 in GFCI 10), while Vienna has remained more or less in the same position (rank 42 in GFCI 10) - a development which corresponds very well with the conclusions given here.

3. The private equity industry consists of, on the one hand a rather small number of large funds located mainly in the USA or the UK such as Blackstone, Apax, KKR and Permira, which are themselves in part public companies, and on the other hand a large number of smaller, unlisted companies (Froud and Williams, 2007). Private equity firms acquire a controlling or substantial minority interest in a company and then attempt to maximise the value of that investment through different arrangements. In general, they receive a return on their investments through public offering or the reselling of their stakes to other (investment) companies.

\section{References}

Baltzarek F (2005) Finanzrevolutionen, Industrialisierung und Credit Mobilier Banken in der Habsburgermonarchie. In: Rathkolb O, Venus $\mathrm{T}$ and Zimmerl U (eds) Bank Austria Creditanstalt. 150 Jahre österreichische Bankengeschichte im Zentrum Europas. Wien: Zolnay, pp. 12-36.

Bassens D, Derudder B and Witlox F (2011) Setting Shari'a standards: on the role, power and spatialities of interlocking Shari'a boards in Islamic financial services. Geoforum 42: 94-103.
Beaverstock JV, Hoyler M, Pain K and Taylor PJ (2001) Comparing London and Frankfurt as World Cities: A Relational Study of Contemporary Urban Change. London: Anglo-German Foundation for the Study of Industrial Society.

Borchardt K (1985) Grundriß der deutschen Wirtschaftsgeschichte. Göttingen: Vandenhoeck und Ruprecht.

Boschma R and Martin R (2010) The aims and the scope of evolutionary economic geography. In: Boschma R and Martin R (eds) The Handbook of Evolutionary Economic Geography. Cheltenham: Edward Elgar, pp. 3-39.

Butschek F (2009) Die CA Krise 1931. Wirtschaft und Gesellschaft 35: 65-78.

Clark GL and Wójcik D (2005) Path dependence and financial markets: the economic geography of the German model, 1997-2003. Environment and Planning A 30: 1769-1791.

Clark GL and Wójcik D (2007) The Geography of Finance: Corporate Governance in a Global Marketplace. Oxford: Oxford University Press.

Deutinger S (2001) Vom Agrarland zum High Tech Staat. Zur Geschichte des Forschungsstandorts Bayern 1945-1980. Munich: Deutsches Museum.

Dosi G (1997) Opportunities, incentives and the collective patterns of technological change. Economic Journal 107: $1530-1547$.

Eigner P (2005) Ein Schritt nach vorne, zwei Schritte zurück - Die wechselhafte Geschichte des Finanzplatzes Wien im 20. Jahrhundert. In: Rathkolb O, Venus T and Zimmerl U (eds) Bank Austria Creditanstalt. 150 Jahre österreichische Bankengeschichte im Zentrum Europas. Wien: Zolnay, pp. 482-501.

Eigner P, Wagner M and Weigl A (1991) Finanzplatz Wien. Wien als Geld- und Kapitalmarkt. In: Chaloupek G and Wagner M (eds) Wien. Wirtschaftsgeschichte 1740 bis 1938. Wien: Jugend und Volk, pp. 909-997.

Engelen E (2003) The logic of funding European pension restructuring and the dangers of financialisation. Environment and Planning $A$ 35: 1357-1372.

Engelen E (2007) 'Amsterdamned'? The uncertain future of a financial centre. Environment and Planning A 39: 1306-1324.

Engelen E and Grote M (2009) Stock exchange virtualisation and the decline of second-tier financial centres: the cases of Amsterdam and Frankfurt. Journal of Economic Geography 9: 679-696.

Faulconbridge JR (2004) London and Frankfurt in Europe's evolving financial centre network. Area 36: 235-244. 
Faulconbridge JR, Engelen E, Hoyler M and Beaverstock J (2007) Analysing the changing landscape of European financial centres: the role of financial products and the case of Amsterdam. Growth and Change 38: 279-303.

Finanzplatz München Initiative (FPMI) (2009) Dynamic for hundreds of years. Available at: www.fpmi.de/en/ initiative/history.html (accessed 7 October 2009).

Fohlen C (1985) Die Industrielle Revolution in Frankreich 1700-1914. In: Cipolla C and Borchardt K (eds) Europäische Wirtschaftsgeschichte. Die Entwicklung der industriellen Gesellschaften 4. Stuttgart: G. Fischer, pp. 87-134.

Folkmann P, Froud J, Sukhdev J and Williams K (2007) Working for themselves? Capital market intermediaries and present day capitalism. Business History 49: $552-572$.

Freeman LC (2005) The Development of Social Network Analysis: A Study in the Sociology of Science. Vancouver, BC, Canada: Empirical Press.

Frenken K and Boschma R (2007) A theoretical framework for evolutionary economic geography: industrial dynamics and urban growth as a branching process. Journal of Economic Geography 7: 635-649.

Friedmann J (1986) The world city hypothesis. Development and Change 17: 69-83.

Froud J and Williams K (2007) Private equity and the culture of value extraction. New Political Economy 12: 405-420.

Gömmel R (2007) Der Aufstieg zum führenden bayerischen Finanzplatz. In: Denzel M and Pohl H (eds) Geschichte des Finanzplatzes München. Munich: Oldenbourg, pp. 91-140.

Graff M (2000) Finanzielle Entwicklung und reales Wirtschaftswachstum. Schriften zur angewandten Wirtschaftsforschung 87. Tübingen: J C B Mohr.

Grote MH (2008) 'Foreign banks' attraction to the financial centre Frankfurt - an inverted ' $U$ ' shaped relationship. Journal of Economic Geography 8: 239-258.

Hall S and Appleyard L (2009) City of London, city of learning? Placing business education within the geographies of finance. Journal of Economic Geography 9: 597-617.

Jansen D (2003) Einführung in die Netzwerkanalyse. Opladen: VS Verlag.

Jungmann-Stadler F (1988) Hypo und Sparkassen im 19. Jahrhundert. Zeitschrift für bayerische Sparkassengeschichte 2: 131-170.

Karreman B (2009) Financial geographies and emerging markets in Europe. Tijdschrift voor Economische en Sociale Geografie 100: 260-266.
Karreman B and Van Der Knaap B (2009) The financial centres of Shanghai and Hong Kong: competition or complementarity? Environment and Planning A 41 563-580.

Klagge B (2004) Finanzstandort Deutschland im Wandel? Rolle und Entwicklung des deutschen Risikokapitalmarktes. Petermanns Geographische Mitteilungen 148: 18-25.

Klagge B and Peter C (2009) Wissensmanagement in Netzwerken unterschiedlicher Reichweite. Das Beispiel des Private equity-Sektors in Deutschland. Zeitschrift für Wirtschaftsgeographie 53: 69-88.

Komlosy A (2006) Österreichs Brückenfunktion und die Durchlässigkeit des 'Eisernen Vorhanges'. In: Enderle-Burcel G, Stiefel D and Teichova A (eds) 'Zarte Bande' Österreich und die europäischen planwirtschaftlichen Länder. Mitteilungen des Österreichischen Staatsarchives, Sonderband 9. Vienna: Studienverlag, pp. 73-105.

Krätke S (2002) Network analysis of production clusters: the Potsdam/Babelsberg film industry as an example. European Planning Studies 10: 27-54.

Kruse C (2005) Börsengänge am Finanzplatz Schweiz. Vernetzte Finanzintermediäre als Erfolgs oder Risikofaktor für Börsenunternehmen? Zurich: ETH Zürich.

Kürten R (2006) Regionale Finanzplätze in Deutschland; Funktionen, Entwicklungen und Gestaltungsansätze. Sternenfels: Verl. Wissenschaft \& Praxis.

Lai K (2012) Differentiated markets: Shanghai, Beijing and Hong Kong in China's financial centre network. Urban Studies 49: 1275-1296.

LfA Förderbank Bayern (ed.) (2001) Chronik: 50 Jahre LfA Förderbank Bayern. Munich: LfA.

Martin R (2006) Pfadabhängigkeit und die ökonomische Landschaft. In: Berndt C and Glückler J (eds) Denkanstöße zu einer anderen Geographie der Ökonomie. Bielefeld: Transcript Verlag, pp. 47-76.

Martin R and Sunley P (2006) Path dependence and the evolution of the economic landscape. Journal of Economic Geography 6: 395-438.

Musil R (2009) Global capital control and city hierarchies: an attempt to reposition Vienna in a world city network. Cities 26: 255-265.

Private Equity Online (2007) Global News and comment on Private Equity Online. Available at: www.privateequityonline.com (accessed 24 October 2008).

Resch A (2006) Wien - die wechselvolle Entwicklung eines Finanzplatzes in Zentraleuropa. In: Der Wissenschaftliche Beirat des Instituts für bankhistorische Forschung (ed.) Europäische Finanzplätze 
im Wettbewerb. Bankhistorisches Archiv, Beiheft 45. Stuttgart: Franz Steiner Verlag, pp. 93-138.

Sassen S (1991) The Global City: London, New York, Tokyo. Princeton, NJ: Princeton University Press.

Schamp EW (2003) Evolution und Institution als Grundlagen einer dynamischen Wirtschaftsgeographie: Die Bedeutung von externen Skalenerträgen für geographische Konzentration. Geographische Zeitschrift 90: 40-51.

Schamp EW (2009) Das Finanzzentrum - ein Cluster? Ein multiskalarer Ansatz und seine Evidenz am Beispiel von Frankfurt/RheinMain. Zeitschrift für Wirtschaftsgeographie 53: 89-105.

Schmit J (2003) Die Geschichte der Wiener Börse. Ein Vierteljahrtausend Wertpapierhandel. Wien: Bibliophile Edition.

Stiefel D (2006) 'Zarte Bande' Österreich und die Planwirtschaftlichen Länder. In: Enderle-Burcel G, Stiefel D and Teichova A (eds) 'Zarte Bande' Österreich und die europäischen planwirtschaftlichen Länder. Mitteilungen des Österreichischen Staatsarchives 9. Vienna: Studienverlag, pp. 13-37.

Supple B (1976) Der Staat und die Industrielle Revolution 1700-1914. In: Cipolla C and Borchardt K (eds) Europäische Wirtschaftsgeschichte. Die Entwicklung der industriellen Gesellschaften 4. Stuttgart: G. Fischer, pp. 195-231.

Taylor PJ (2001) Specification of the world city network. Geographical Analysis 33: 181-194.

Taylor PJ (2004) World City Network: A Global Urban Analysis. London, New York: Routledge.

Trappmann M, Hummel HJ and Sodeur W (2005) Strukturanalyse sozialer Netzwerke. Konzepte, Modelle, Methoden. Wiesbaden: VS-Verlag.
Wagner-Braun M (2007) Münchens Finanzgewerbe zwischen Staatswirtschaft und Industrialisierung. In: Denzel $\mathrm{M}$ and Pohl $\mathrm{H}$ (eds) Geschichte des Finanzplatzes München. Munich: Oldenbourg, pp. 41-90.

Wiener Börse (2006) Geschichte der Wiener Börse. Available at: www.wienerborse.at/static/cms/sites/ wbag/media/de/pdf/about/geschichte.pdf (accessed 26 February 2009).

Wójcik D (2007) Geography and future of stock exchanges: between real and virtual space. Growth and Change 38: 200-223.

Wójcik D (2011) The dark side of NY-LON: financial centres and the global financial crisis. Employment, Work and Finance Working Paper no. 11-12. Oxford: University of Oxford.

Zademach H-M (2009) Global finance and the development of regional clusters: tracing paths in Munich's film and TV industry. Journal of Economic Geography 9: 697-722.

Zademach H-M (2011) Ökonomie(n) der Vielfalt: Wissensvernetzung, Finanzbeziehungen und technologischer Wandel in München. Geographische Zeitschrift 99: 143-162.

Zademach H-M and Rodríguez-Pose A (2009) Crossborder M\&As and the changing economic geography of Europe. European Planning Studies 17: 765-789.

Zeitler FC (2007) Der Beitrag des bayerischen Finanzdienstleistungsgewerbes zum Wandel der bayerischen Wirtschaftsstruktur nach dem Zweiten Weltkrieg. In: Denzel $\mathrm{M}$ and Pohl $\mathrm{H}$ (eds) Geschichte des Finanzplatzes München. Munich: Oldenbourg, pp. $185-244$.

Z/Yen (2010) Global Financial Centres 7. London: Z/Yen. 


\section{Appendix}

Table 5. Characteristics of the top I5 European financial centres, 2009.

\begin{tabular}{|c|c|c|c|c|c|}
\hline & GFCl 7 rank & $\begin{array}{l}\text { Headquarters of } \\
\text { top } 30 \text { banks }\end{array}$ & $\begin{array}{l}\text { Subsidiaries of } \\
\text { top } 30 \text { banks }\end{array}$ & $\begin{array}{l}\text { Headquarters of } \\
\text { top } 50 \mathrm{PE} \text { firms }\end{array}$ & $\begin{array}{l}\text { Subsidiaries of top } \\
50 \mathrm{PE} \text { firms }\end{array}$ \\
\hline Amsterdam & 35 & 1 & 7 & - & 4 \\
\hline Brussels & 39 & 2 & 10 & - & 1 \\
\hline Copenhagen & 41 & 1 & 2 & - & 4 \\
\hline Dublin & 31 & - & 8 & - & 2 \\
\hline Edinburgh & 29 & 1 & 6 & - & - \\
\hline Frankfurt & 13 & 1 & 6 & - & 16 \\
\hline Geneva & 8 & - & 6 & - & 2 \\
\hline London & 1 & 4 & 22 & 10 & 28 \\
\hline Luxembourg & 19 & - & 16 & I & 7 \\
\hline Madrid & 45 & I & 19 & - & 11 \\
\hline Munich & 33 & - & 3 & - & 8 \\
\hline Paris & 20 & 4 & 53 & 2 & 17 \\
\hline Stockholm & 38 & 2 & 4 & I & 8 \\
\hline Vienna & 43 & 1 & 6 & - & 2 \\
\hline Zurich & 7 & 2 & 5 & - & 6 \\
\hline
\end{tabular}

Sources: Z/Yen (2010), authors' calculations based on data from Bankscope Database and own data collection.

GFCl: Global Financial Centres Index.

Table 6. Milestones in the history of the financial industry in Munich.

\begin{tabular}{ll}
\hline 1486 & The Fugger Brothers trading house in Augsburg was designated for the first time as a bank. It \\
developed into today's private bank Fürst Fugger \\
In Augsburg, the first German bourse was founded. In the same year, a securities trading centre in \\
Nuremberg was established \\
In Ansbach, Margrave Karl Alexander founded Hochfürstlich Brandenburg Anspach Bayreuthische \\
Hofbanco, which later became the Bavarian state bank \\
The \\
The first concrete proposal for establishing a savings bank in Bavaria (rejected) \\
1807 & The Augsburg bourse started securities trading \\
1816 & The first Bavarian savings bank was opened in Nuremberg \\
1821 & Foundation of Sparkasse Munich \\
1824 & Opening of the Munich exchange \\
1830 & Foundation of Bayerischen Hypotheken und Wechsel Bank AG \\
1835 & Munich Loan Association (today Münchner Bank eG), Bavaria's first cooperative associations, and a \\
$1860 / 70 s$ & number of private banks (e.g. Merck, Finck \& Co,Aughäuser KG) were established \\
1880 & Foundation of Münchner Rück \\
1909 & Foundation of Vereinigung Münchner Banken \& Bankiers \\
1920 & The Bavarian state government relocates Bayerische Staatsbank's headquarters from Nuremberg to \\
1935 & Munich \\
1949 & Merger of the Munich and Augsburg exchanges into the Bavarian Exchange, headquartered in \\
& Munich \\
Relocation of Allianz Versicherungs AG's head office from Berlin to Munich
\end{tabular}


Table 6. (Continued)

1949

1967

1972

1991

1998

2000

2000

2001

2003

2005

2005

2007
Foundation of first German mutual fund,ADIG Investment Introduction of saving certificates

Merger of Landesbodenkreditanstalt and Bayerische Gemeindebank into Bayerische Landesbank, the parent bank of the Bavarian savings banks

Allianz acquires the US insurance company, Fireman's Fund

Merger of Hypo Bank and Bayerische Vereinsbank into Bayerische Hypo and Vereinsbank AG (HVB), thus creating Germany's second largest bank

As part of Europe's first cross-border bank merger, HVB integrates Bank Austria into its operations Foundation of the Munich Financial Centre Initiative at the urging of Otto Wiesheu, the Bavarian State Minister of Economic Affairs

Allianz acquires Germany's third largest financial institution, Dresdner Bank, headquartered in Frankfurt

The Munich exchange introduces the Max One trading system

With 'M:access', the Munich Exchange launches a new market segment for SMEs

The heads of HVB and the Italian UniCredit agree on the largest European bank merger ever

Hypo Real Estate Holding AG takes over DEPFA Bank, one of the world's leading providers of financial services to public sector entities and authorities

Source: FPMI, 2009 (modified).

SME: small and medium-sized enterprise.

Table 7. Milestones in the history of the financial industry in Vienna.

$1706 \quad$ Founding of 'Viennese Stadt Baco' for the government's debt management

177I Founding of the Viennese bourse by Empress Maria Theresia as the first bourse in central Europe.

Main task was the trading of state bonds

1816

Founding of the Austrian national bank to avoid currency fluctuations

1842

First boom phase at the Viennese bourse, caused by emission of railway stocks

1845

Government avoided crash after speculative bubble by buying up all railway stocks

1855

Founding of k.k. priv. Österreichische Credit Anstalt für Handel und Gewerbe. This bank (later:

Creditanstalt) has dominated the Viennese financial market up to the present. Other later

dominating banks were founded in the following years

I866 Beginning of the first Gründerzeit, where the large Viennese banks had an important role in financing industry and railway companies

1873 The boom phase finally ended in the Börsenkrach, the first international financial crisis. While the dominating banks managed the crisis well, many investment banks did not

1893 Begin of the second Gründerzeit:Vienna became an important national and international financial place. Twelve Viennese banks dominated the financial market in Vienna, and also Prague and Budapest

1918 Vienna lost its role as an international financial market; in 1924 the equity capital of Viennese banks amounted to just a fifth of that of 1914

1931 Collapse of Creditanstalt marked the end of all efforts to establish Vienna as a financial market place for eastern central Europe.

1945-1955 Nationalisation of industries and (to a lesser degree) of the financial sector. European Recovery Programme credits and bank credits dominate for industry funding

1980

1989

First de-regulation on a national level, mergers between banks and privatisation were allowed

Transformation in Comecon countries as the beginning of internationalisation of Viennese banks. First subsidiary in central and eastern European countries founded by Creditanstalt in November 1989. Successful mergers were initiated by Viennese and Austrian banks in eastern Europe

De-regulation of the financial sector in Austria. Wiener Zentralsparkasse and Länderbank merged to form Bank Austria. Many mergers followed 
Table 7. (Continued)

1997 Bank Austria merged with Creditanstalt to become Austria's largest bank.

Erste Bank merged with GiroCredit

$1998 \quad$ Viennese stock market turnover increased between 1987 and 1998 from 2.3 to 33.1 billion Euros. This development was caused by the deregulation of financial market control as well as by the privatisation of state-owned industries

2000 Bavarian HVB merged Bank Austria. 2005 HVB merged to UniCredit

2002 Ongoing consolidation within the banking sector: top 10 Austrian banks hold $76.6 \%$ of registered shares

2003 Shareholdings of Viennese banks in eastern Europe amount to about 174.2 billion Euros. The most important foreign banks in this region are located in Vienna (Bank Austria/UniCredit, Erste Bank, Raiffeisen); total marked share $17.1 \%$

2004 Cooperation of Vienna bourse with Budapest, Ljubljana followed in 2008

$2008 \quad$ Cerberus merged with Bawag

Sources: Karreman, 2009; Resch, 2006; Stiefel, 2006. 